medRxiv preprint doi: https://doi.org/10.1101/2021.06.09.21258157; this version posted June 13, 2021. The copyright holder for this preprint (which was not certified by peer review) is the author/funder, who has granted medRxiv a license to display the preprint in perpetuity.

\title{
Evaluation and clinical implications of the time to a positive results of antigen testing
}

\section{for SARS-CoV-2}

Yusaku Akashi ${ }^{1,2, *}$, Yoshihiko Kiyasu ${ }^{1,3}$, Yuto Takeuchi ${ }^{1,3}$, Daisuke Kato ${ }^{4}$, Miwa Kuwahara $^{4}$, Shino Muramatsu ${ }^{4}$, Atsuo Ueda ${ }^{5}$, Shigeyuki Notake ${ }^{5}$ Koji Nakamura ${ }^{5}$, Hiroichi Ishikawa $^{6}$, and Hiromichi Suzuki ${ }^{1,3,7}$

${ }^{1}$ Division of Infectious Diseases, Department of Medicine, Tsukuba Medical Center Hospital, 1-3-1 Amakubo Tsukuba, Ibaraki 3058558, Japan

${ }^{2}$ Akashi Internal Medicine Clinic, 3-1-63 Asahigaoka, Kashiwara, Osaka 5820026, Japan

${ }^{3}$ Department of Infectious Diseases, University of Tsukuba Hospital, 2-1-1 Amakubo, Tsukuba, Ibaraki 3058576, Japan

${ }^{4}$ Research \& Development Division, Reagent R\&D Department, Gosen site, Denka Co., Ltd., 1-2-2 Minamihoncho, Gosen-shi, Niigata 9591695, Japan

${ }^{5}$ Department of Clinical Laboratory, Tsukuba Medical Center Hospital, 1-3-1 Amakubo, Tsukuba, Ibaraki 3058558, Japan

${ }^{6}$ Department of Respiratory Medicine, Tsukuba Medical Center Hospital, 1-3-1 Amakubo, Tsukuba, Ibaraki 3058558, Japan

${ }^{7}$ Department of Infectious Diseases, Faculty of Medicine, University of Tsukuba, 1-1-1 Tennodai, Tsukuba, Ibaraki 3058575, Japan

E-mail addresses of each author: Yusaku Akashi, yusaku-akashi@umin.ac.jp; Yoshihiko Kiyasu, kiyasu-tuk@umin.ac.jp; Yuto Takeuchi, yuto-takeuchi@umin.ac.jp; Daisuke Kato, daisuke-kato@denka.co.jp; Miwa Kuwahara, miwaNOTE: This preprint reports new research that has not been certified by peer review and should not be used to guide clinical practice. 
medRxiv preprint doi: https://doi.org/10.1101/2021.06.09.21258157; this version posted June 13, 2021. The copyright holder for this preprint (which was not certified by peer review) is the author/funder, who has granted medRxiv a license to display the preprint in perpetuity.

It is made available under a CC-BY-NC-ND 4.0 International license .

kuwahara@denka.co.jp; Shino Muramatshu, shino-muramatsu@denka.co.jp; Atsuo Ueda, atsuo.ueda06090727@outlook.jp; Shigeyuki Notake, notake@tmch.or.jp; Koji Nakamura, koji-nakamura@tmch.or.jp; Hiroichi Ishikawa, hishikawa@tmch.or.jp; Hiromichi Suzuki, hsuzuki@md.tsukuba.ac.jp

Keywords: antigen test, COVID-19, SARS-CoV-2, time to positive results, QuickNavi ${ }^{\text {TM_COVID19 Ag }}$

Running head: Time to positive results of antigen testing for SARS-CoV-2

Word count: abstract, 250; body 1809

\section{Correspondence to Yusaku Akashi}

Division of Infectious Diseases, Department of Medicine, Tsukuba Medical Center Hospital, 1-3-1 Amakubo Tsukuba, Ibaraki 305-8558, Japan

Tel: $+81-029-851-3511$

E-mail: yusaku-akashi@umin.ac.jp

ORCID ID: 0000-0001-9789-8301 
medRxiv preprint doi: https://doi.org/10.1101/2021.06.09.21258157; this version posted June 13, 2021. The copyright holder for this preprint (which was not certified by peer review) is the author/funder, who has granted medRxiv a license to display the preprint in perpetuity.

\begin{abstract}
Antigen tests for severe acute respiratory coronavirus 2 sometimes show positive lines earlier than their specified read time, although the implication of getting the results at earlier time is not well understood. This study aimed to evaluate the clinical utility of an antigen test by evaluating the time period to get positive results and by comparing the test sensitivity with that of a digital immunoassay (DIA) test.
\end{abstract}

We prospectively collected additional nasopharyngeal samples from patients who had already tested positive for SARS-CoV-2 by reverse transcription PCR. The additional swab was used for an antigen test, QuickNavi ${ }^{\text {TM}}$-COVID19 Ag, and the time periods to get positive results were measured. The sensitivity of QuickNavi ${ }^{\mathrm{TM}_{-} \text {COVID19 }}$ Ag was also compared with that of a DIA.

In 84 of $96(87.5 \%)$ analyzed cases, the results of QuickNavi ${ }^{\text {TM_COVID19 Ag }}$ were positive. The time to obtain positive results was 15.0 seconds in median (inter quartile range: 12.0-33.3, range 11-736), and was extended in samples with higher cycle thresholds $(\mathrm{Ct})(p<0.001)$. Positive lines appeared within a minute in $85.7 \%$ of cases and within 5 minutes in $96.4 \%$. The sensitivities of QuickNavi ${ }^{\text {TM}}-$ COVID19 Ag and the DIA were $87.5 \%$ (95\% confident interval [CI]: 79.2\%-93.4\%) and 88.6\% (95\%CI: $75.4 \%-$ $96.2 \%$ ), respectively. Their results were concordant in $90.9 \%$ of cases, with discrepancies present only in cases with $\mathrm{Ct}$ values $>32$.

QuickNaviTM_COVID19 Ag immediately showed positive results in most cases, and the time to a positive reaction may have indicated the viral load. In addition, the sensitivity of the test was comparable to the DIA. 
medRxiv preprint doi: https://doi.org/10.1101/2021.06.09.21258157; this version posted June 13, 2021. The copyright holder for this preprint (which was not certified by peer review) is the author/funder, who has granted medRxiv a license to display the preprint in perpetuity.

\section{Introduction}

The global pandemic caused by severe acute respiratory coronavirus 2 (SARSCoV-2) remains a concern and is unlikely to end soon [1]. Until the pandemic is under control, early diagnosis and screening with effective test modalities are essential strategies to combat the disease [2].

Antigen tests originally had low sensitivity compared to nucleic examinations [3]. Their diagnostic performance has improved over time [4], and previous research has found them beneficial for screening purposes [5] or in low-resource settings [6]. Advantages of antigen tests include the ability to analyze multiple samples simultaneously, the lack of a need for special equipment, and the fast turnaround time (TAT).

Manufacturers of antigen tests recommend that the results be read 10-30 minutes after sample placement [3]. Positive lines sometimes appear before the manufacturer's specified time, although the clinical implication of an early detection is not well understood. Knowing the time to a positive reaction in clinical samples may help identify a more appropriate read time, which could reduce their overall TAT.

We previously evaluated the diagnostic performance of QuickNavi ${ }^{\text {TM_COVID19 }}$ Ag (Denka Co., Ltd., Tokyo, Japan), revealing a sensitivity of $86.7 \%$ and a specificity of $100 \%$ [7], with a read time of 15 minutes. The sensitivity seemed sufficient, although the limit of detection was inferior to that of a rapid immunochromatography, which utilizes a digital immunoassay (DIA) platform [8]. The head-to-head comparison using clinical samples has been awaited to validate their test performances.

In this study, we aimed to clarify the clinical utility of QuickNavi ${ }^{\text {TM_COVID19 }}$ Ag by evaluating the time periods to get positive results and by comparing its sensitivity 
medRxiv preprint doi: https://doi.org/10.1101/2021.06.09.21258157; this version posted June 13, 2021. The copyright holder for this preprint (which was not certified by peer review) is the author/funder, who has granted medRxiv a license to display the preprint in perpetuity.

It is made available under a CC-BY-NC-ND 4.0 International license .

with an immunochromatography test, which comes with a DIA reader.

\section{Methods}

Between January 25, 2021, and March 27, 2021, we prospectively evaluated the time necessary for positive reactions in two antigen tests; one is QuickNavi ${ }^{\text {TM}}$-COVID19 $\mathrm{Ag}$, which is already on the market with 15 minutes read time, and the other is its improved product (DK20-CoV-8M). Nasopharyngeal samples were obtained from SARS-CoV-2-positive patients after they provided informed consent. The ethics committee of Tsukuba Medical Center Hospital (TMCH) approved the present study (approval number: 2020-033).

\section{Study sites and patient backgrounds}

This study was performed at a drive-through-type PCR center located at TMCH in Tsukuba, Japan. The PCR center performed in-house RT-PCR examinations [7] of residents of the Tsukuba district who were referred from a local public health center and primary care facilities (Figure 1). PCR examination was performed immediately after each nasopharyngeal sampling, and the results were reported to both patients and doctors within a few hours. Physicians then assessed the risk factors and disease severity of PCRpositive patients (Figure 1).

\section{Sample collection and antigen test procedures}

In the current study, an additional nasopharyngeal sample was obtained from inhouse PCR-positive patients using FLOQSwab ${ }^{\mathrm{TM}}$ (Copan Italia S.p.A., Brescia, Italy), using a previously described technique [9]. The swab sample was diluted with specimen 
medRxiv preprint doi: https://doi.org/10.1101/2021.06.09.21258157; this version posted June 13, 2021. The copyright holder for this preprint (which was not certified by peer review) is the author/funder, who has granted medRxiv a license to display the preprint in perpetuity.

It is made available under a CC-BY-NC-ND 4.0 International license.

buffer provided in a tube, which is included in the test kit, and commonly used for the two antigen tests. The tests were simultaneously performed according to the manufacturers' instructions (Figure 2), and examiners visually interpreted the results. The required time for positive results was measured with a stopwatch after specimens were added to the test cassette. If the line indicating positivity was not visualized, the results were recorded as negative.

\section{Copy numbers and $\mathrm{Ct}$ values of PCR examination in comparison with the required} time for positive results of antigen test

All the antigen test evaluations were performed on the same day of sampling specimens for RT-PCR examinations. The RT-PCR examinations used nasopharyngeal samples suspended in $3 \mathrm{~mL}$ of $\mathrm{UTM}^{\mathrm{TM}}$ (Copan Italia S.p.A.). After extraction with a magLEAD 6gC (Precision System Science Co., Ltd., Chiba, Japan), the eluted samples were first tested with in-house PCR. Rest of the eluted RNA were stored at $-80{ }^{\circ} \mathrm{C}$ and were transferred to Denka Co., Ltd., every week for real-time RT-PCR of SARS-CoV-2. The examination employed the QuantStudio ${ }^{\circledR} 3$ Real-Time PCR System (Thermo Fisher Scientific Inc., MA, USA) and a method developed by the National Institute of Infectious Diseases (NIID), Japan [10]. The NIID N/N2 SARS-CoV-2 Standard (Nihon Gene Research Laboratories, Inc., Japan) was used as a control to make a standard curve for the analysis of copy numbers.

\section{Comparison between QuickNaviTM-COVID19 Ag and DIA}

During the study period, antigen testing was performed with both QuickNavi ${ }^{\text {TM}_{-}}$ COVID19 Ag and QuickChaser Auto SARS-CoV-2 (Mizuho Medy Co., Ltd.) at the 
medRxiv preprint doi: https://doi.org/10.1101/2021.06.09.21258157; this version posted June 13, 2021. The copyright holder for this preprint (which was not certified by peer review) is the author/funder, who has granted medRxiv a license to display the preprint in perpetuity.

It is made available under a CC-BY-NC-ND 4.0 International license .

drive-through-type PCR center. We compared the analytical sensitivity for the detection of SARS-CoV-2 between the two antigen tests. The results of real-time RT-PCR of SARS$\mathrm{CoV}-2$ were used as the reference standard.

\section{Statistical analyses}

The sensitivity of antigen testing was calculated using the Clopper and Pearson method, with $95 \%$ confident intervals $(95 \% \mathrm{CI})$. Linear regression analysis was used to describe the relationship between two continuous variables; $p$-values $<0.05$ were considered to represent statistically significant differences. All calculations were conducted using R 4.0.4 (The R Foundation, Vienna, Austria).

\section{Results}

The study included 96 patients who were positive for SARS-CoV-2 by RT-PCR, of whom $52(54.2 \%)$ were symptomatic. The RT-PCR examination detected the N2 gene in all patients and failed to identify the $\mathrm{N}$ gene in 11 . The median number of viral copies per test and the median $\mathrm{Ct}$ values were 360,000 (inter quartile range [IQR]: 22,0002,300,000) and 28.0 (IQR: 25.0-32.0) for the $\mathrm{N}$ gene, and 1,250,000 (IQR: 82,75020,500,000) and 24.0 (IQR: 19.8-28.0) for the N2 gene. The numbers of cases with an N2 gene $\mathrm{Ct}$ of $<20,20-30$, and $\geq 30$ were 24,52 , and 20 , respectively.

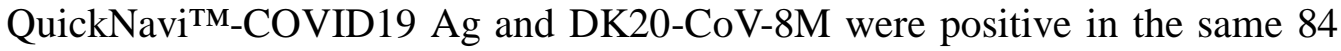
patients; thus, their sensitivities were $87.5 \%$ (95\% CI: 79.2\%-93.4\%) when using N2 gene RT-PCR as a reference (Table 1). False negatives occurred in 12 patients, and in all of them the $\mathrm{N} 2$ gene $\mathrm{Ct}$ values were $>32$. 
medRxiv preprint doi: https://doi.org/10.1101/2021.06.09.21258157; this version posted June 13, 2021. The copyright holder for this preprint (which was not certified by peer review) is the author/funder, who has granted medRxiv a license to display the preprint in perpetuity.

It is made available under a CC-BY-NC-ND 4.0 International license .

\section{Time required to get positive results for QuickNaviTM-COVID19 Ag and DK20-CoV-}

\section{M}

The median time to get positive results was 15.0 seconds (IQR: 12.0-33.3, range 11-736) with QuickNavi'TM_COVID19 Ag and 21.0 seconds (IQR: 17.0-44.3, range: 11736) with DK20-CoV-8M (Table 1).

Positive lines were observed within a minute in $85.7 \%$ of samples analyzed with

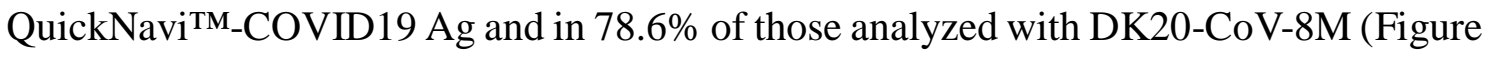
3). In $96.4 \%$ of cases, both tests can be interpreted as positive within 5 minutes. The time required to get positive results for the two antigen tests was significantly correlated, as shown in the Supplementary Figure $(p<0.001)$. In three cases, more than 5 minutes were required to obtain positive results in both antigen tests; their Ct values were 28,34 , and 38 , respectively.

As depicted in Figure 3, there was a linear association between the time required to get positive results and $\mathrm{Ct}$ values ( $\mathrm{N} 2$ gene) in samples $(p<0.001)$.

\section{Concordance of QuickNaviTM_COVID19 Ag with DIA}

Of the 96 included patients, 44 provided samples for antigen testing by the DIA, and the results were concordant with those of QuickNavi ${ }^{\text {TM}}$-COVID19 Ag in $90.9 \%$ of cases (40/44). Both tests exhibited positive results in all samples with N2 gene Ct values $\leq 31$ (Figure 4). Discordant results were observed in four samples: in two, with Ct values of 36 and 38, respectively, QuickNavi ${ }^{\text {TM}}$-COVID19 Ag was positive while the DIA was negative, while in the other two, with Ct values of 33 and 34, respectively, QuickNavi ${ }^{\mathrm{TM}_{-}}$ COVID19 Ag was negative and the DIA was positive. Neither antigen test could detect the virus in three samples with $\mathrm{Ct}$ values of 34 and 36, respectively. 
medRxiv preprint doi: https://doi.org/10.1101/2021.06.09.21258157; this version posted June 13, 2021. The copyright holder for this preprint (which was not certified by peer review) is the author/funder, who has granted medRxiv a license to display the preprint in perpetuity.

\section{Discussion}

The median time to get positive results was 15 seconds for QuickNavi ${ }^{\mathrm{TM}_{-}}$ COVID19 Ag, and $85.7 \%$ and $96.4 \%$ of patient samples resulted in positive reactions within 1 and 5 minutes, respectively. The required time to obtain positive results was significantly lengthened as the $\mathrm{Ct}$ values of samples increased. Direct comparison using

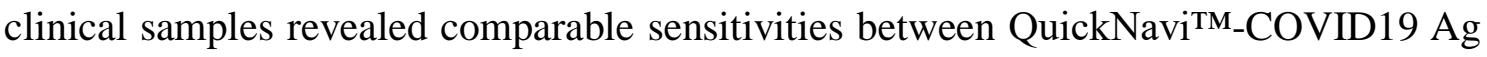
and the DIA.

The Centers for Disease Control and Prevention recommend that in order to avoid false negatives, the results should be read at the time designated by the manufacturer [11]. According to the manufacturer's instruction for use, however, QuickNavi ${ }^{\text {TM}}-$ COVID19 Ag can be interpreted as positive once the positive line is visualized even before the specified read time. In our study, about $80 \%$ of positive cases can be tested within 1 minute and over $90 \%$ within 5 minutes, which is faster than designated read time. The manufacturer's specified time, therefore, may be longer than necessary (Figure 3). This finding might apply to other antigen tests, although variations in performance possibly exist due to methodological differences among products [12].

The time period to obtain positive results extended proportionally with the $\mathrm{Ct}$ value; hence, the time required to be positive may indicate the viral load in a given sample. In our study, the time needed more than 10 minutes was limited to the cases with a $\mathrm{Ct}$ value $>30$. Given that these samples are generally culture negative [13], positive lines that appears more than a few minutes may imply a low viral load with a smaller risk of transmissivity to others. Viral load is associated with disease severity [14] in addition to transmissivity. A shorter reaction time in antigen tests might predict disease severity, 
medRxiv preprint doi: https://doi.org/10.1101/2021.06.09.21258157; this version posted June 13, 2021. The copyright holder for this preprint (which was not certified by peer review) is the author/funder, who has granted medRxiv a license to display the preprint in perpetuity.

It is made available under a CC-BY-NC-ND 4.0 International license .

considering that reaction time was employed in a clinical score to predict the severity of pneumococcal pneumonia [15]. Further studies should be conducted to evaluate the clinical usefulness of measuring the time to get positive results in various antigen tests.

We expected DIA to have a higher sensitivity than QuickNavi ${ }^{\text {TM}}-$ COVID19 Ag because of its lower limit of detection and its implementation of a digital immunoassay system [8]. However, the two tests had almost identical sensitivity when used with clinical samples. The reactivity of antigen tests can differ between clinical and $\mathrm{UTM}^{\mathrm{TM}}$ samples. QuickNavi ${ }^{\text {TM}}-$ COVID19 Ag detected the virus in almost all clinical samples with $\mathrm{Ct}$ values $<30$ when the supplied extraction reagent was used $[7,16]$, but the sensitivity plummeted when samples were diluted in UTM ${ }^{\mathrm{TM}}$ [17]. Measuring the limit of detection seems insufficient to verify the clinical performance of antigen tests. In this study, four samples produced discordant results between the two tests, and all of them had Ct values $>30$. These discrepancies can be explained by the stochastic effects involved in detecting the virus in samples with low viral loads.

This study had several limitations. First, it did not include patients who were confirmed to be negative for SARS-CoV-2 by RT-PCR. The relationship between QuickNavi ${ }^{\text {TM}}$-COVID19 Ag read times and the possibility of false positives was not evaluated, although we previously confirmed false positives are merely seen with this test [7]. Further, we could not compare the specificities of QuickNavi ${ }^{\text {TM}_{-}}$COVID19 Ag and the DIA evaluated. Second, we did not assess whether differences in strains or sample characteristics (e.g., viscosity, blood inclusion) influenced the time to get positive results.

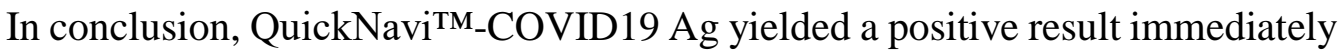
after sample placement in most cases, and the time needed for final interpretation was longer in samples with larger $\mathrm{Ct}$ values. The sensitivity was comparable to that of the 
DIA.

\section{ACKNOWLEDGEMENTS}

We thank all staff at the Department of Clinical Laboratory of Tsukuba Medical Center Hospital who contributed to this study, and all medical institutions that provided their patients' clinical information.

\section{Conflicts of Interest}

Denka Co., Ltd., and Mizuho Medy Co., Ltd. provided test kits free of charge. Regarding this study, Hiromichi Suzuki received lecture fees from Denka Co., Ltd., and Otsuka Pharmaceutical Co., Ltd., and a consultation fee from Mizuho Medy Co., Ltd. Daisuke Kato, Miwa Kuwahara, and Shino Muramatsu are employed by Denka Co., Ltd., the developer of QuickNavi ${ }^{\text {TM}}-$ COVID19 Ag. 
medRxiv preprint doi: https://doi.org/10.1101/2021.06.09.21258157; this version posted June 13, 2021. The copyright holder for this preprint (which was not certified by peer review) is the author/funder, who has granted medRxiv a license to display the preprint in perpetuity.

\section{References}

[1] World Health Organization. Coronavirus disease (COVID-19) Weekly Epidemiological Update and Weekly Operational Update, (2021) Accessed June 1 2021. https://www.who.int/emergencies/diseases/novel-coronavirus2019/situation-reports.

[2] Centers for Disease Control and Prevention. Testing Strategies for SARS-CoV-2, (2021) Accessed June 1 2021. https://www.cdc.gov/coronavirus/2019ncov/lab/resources/sars-cov2-testing-strategies.html.

[3] World Health Organization. Antigen-detection in the diagnosis of SARS-CoV-2 infection using rapid immunoassays, (2020) Accessed May 232021. https://www.who.int/publications/i/item/antigen-detection-in-the-diagnosis-of-sarscov-2infection-using-rapid-immunoassays.

[4] H.C.J.T. Obama, N.A.M. Yousif, L.A. Nemer, P.M.N. Ngougoue, G.A. Ngwa, M. Teboh-Ewungkem, K.A. Schneider, Preventing COVID-19 spread in closed facilities by regular testing of employees-An efficient intervention in long-term care facilities and prisons?, PLOS ONE. $16 \quad$ (2021) e0249588. https://doi.org/10.1371/journal.pone.0249588.

[5] K.L. Schwartz, A.J. McGeer, I.I. Bogoch, Rapid antigen screening of asymptomatic people as a public health tool to combat COVID-19, CMAJ. 193 (2021) E449-E452. https://doi.org/10.1503/cmaj.210100.

[6] Y. Boum, K.N. Fai, B. Nikolay, A.B. Mboringong, L.M. Bebell, M. Ndifon, A. Abbah, R. Essaka, L. Eteki, F. Luquero, C. Langendorf, N.F. Mbarga, R.G. Essomba, B.D. Buri, T.M. Corine, B.T. Kameni, N. Mandeng, M. Fanne, A.-C.Z.-K. Bisseck, C.B. Ndongmo, S. Eyangoh, A. Hamadou, J.P. Ouamba, M.T. Koku, R. Njouom, 
medRxiv preprint doi: https://doi.org/10.1101/2021.06.09.21258157; this version posted June 13, 2021. The copyright holder for this preprint (which was not certified by peer review) is the author/funder, who has granted medRxiv a license to display the preprint in perpetuity.

O.M. Claire, L. Esso, E. Epée, G.A.E. Mballa, Performance and operational feasibility of antigen and antibody rapid diagnostic tests for COVID-19 in symptomatic and asymptomatic patients in Cameroon: a clinical, prospective, diagnostic accuracy study, Lancet Infect Dis. (2021). https://doi.org/10.1016/S14733099(21)00132-8.

[7] Y. Takeuchi, Y. Akashi, D. Kato, M. Kuwahara, S. Muramatsu, A. Ueda, S. Notake, K. Nakamura, H. Ishikawa, H. Suzuki, The evaluation of a newly developed antigen test (QuickNavi ${ }^{\mathrm{TM}}-\mathrm{COVID} 19 \mathrm{Ag}$ ) for SARS-CoV-2: A prospective observational study in Japan, J Infect Chemother. 27 (2021) 890-894. https://doi.org/10.1016/j.jiac.2021.02.029.

[8] Y. Kurihara, Y. Kiyasu, Y. Akashi, Y. Takeuchi, K. Narahara, S. Mori, T. Takeshige, S. Notake, A. Ueda, K. Nakamura, H. Ishikawa, H. Suzuki, The evaluation of a novel digital immunochromatographic assay with silver amplification to detect SARS-CoV-2, MedRxiv. $\quad$ (2021) 2021.05.06.21256738. https://doi.org/10.1101/2021.05.06.21256738.

[9] F.M. Marty, K. Chen, K.A. Verrill, How to Obtain a Nasopharyngeal Swab $\begin{array}{lllllll}\text { Specimen, } & \mathrm{N} & \text { Engl } & \mathrm{J} & \text { Med. } & 382 & \text { (2020) }\end{array}$ https://doi.org/10.1056/NEJMvcm2010260.

[10] K. Shirato, N. Nao, H. Katano, I. Takayama, S. Saito, F. Kato, H. Katoh, M. Sakata, Y. Nakatsu, Y. Mori, T. Kageyama, S. Matsuyama, M. Takeda, Development of Genetic Diagnostic Methods for Detection for Novel Coronavirus 2019(nCoV2019) in Japan, Jpn J Infect Dis. 73 (2020) 304-307. https://doi.org/10.7883/yoken.JJID.2020.061.

[11] Centers for Disease Control and Prevention. Interim Guidance for Antigen Testing 
medRxiv preprint doi: https://doi.org/10.1101/2021.06.09.21258157; this version posted June 13, 2021. The copyright holder for this preprint (which was not certified by peer review) is the author/funder, who has granted medRxiv a license to display the preprint in perpetuity.

It is made available under a CC-BY-NC-ND 4.0 International license.

for $\quad$ SARS-CoV-2, (2021) Accessed $\quad$ May 2821.

https://www.cdc.gov/coronavirus/2019-ncov/lab/resources/antigen-testsguidelines.html.

[12] U.S. FOOD \& DRU Administration. In Vitro Diagnostics EUAs - Antigen Diagnostic Tests for SARS-CoV-2, (2021). Accessed May 282021. https://www.fda.gov/medical-devices/coronavirus-disease-2019-covid-19emergency-use-authorizations-medical-devices/in-vitro-diagnostics-euas-antigendiagnostic-tests-sars-cov-2.

[13] T. Jefferson, E.A. Spencer, J. Brassey, C. Heneghan, Viral cultures for COVID-19 infectious potential assessment - a systematic review, Clinical Infectious Diseases. (2020) ciaa1764. https://doi.org/10.1093/cid/ciaa1764.

[14] J. Fajnzylber, J. Regan, K. Coxen, H. Corry, C. Wong, A. Rosenthal, D. Worrall, F. Giguel, A. Piechocka-Trocha, C. Atyeo, S. Fischinger, A. Chan, K.T. Flaherty, K. Hall, M. Dougan, E.T. Ryan, E. Gillespie, R. Chishti, Y. Li, N. Jilg, D. Hanidziar, R.M. Baron, L. Baden, A.M. Tsibris, K.A. Armstrong, D.R. Kuritzkes, G. Alter, B.D. Walker, X. Yu, J.Z. Li, SARS-CoV-2 viral load is associated with increased disease severity and mortality, Nat Commun. $11 \quad$ (2020) 5493. https://doi.org/10.1038/s41467-020-19057-5.

[15] C.-F. Shen, S.-M. Wang, C.-C. Liu, A new urinary antigen test score correlates with severity of pneumococcal pneumonia in children, J Formos Med Assoc. 110 (2011) 613-618. https://doi.org/10.1016/j.jfma.2011.08.002.

[16] Y. Kiyasu, Y. Takeuchi, Y. Akashi, D. Kato, M. Kuwahara, S. Muramatsu, S. Notake, A. Ueda, K. Nakamura, H. Ishikawa, H. Suzuki, Prospective analytical performance evaluation of the QuickNavi ${ }^{\mathrm{TM}}$-COVID19 Ag for asymptomatic individuals, 
medRxiv preprint doi: https://doi.org/10.1101/2021.06.09.21258157; this version posted June 13, 2021. The copyright holder for this preprint (which was not certified by peer review) is the author/funder, who has granted medRxiv a license to display the preprint in perpetuity. It is made available under a CC-BY-NC-ND 4.0 International license .

MedRxiv.

2021.04.01.21254813.

https://doi.org/10.1101/2021.04.01.21254813.

[17] S. Yamayoshi, Y. Sakai-Tagawa, M. Koga, O. Akasaka, I. Nakachi, H. Koh, K. Maeda, E. Adachi, M. Saito, H. Nagai, K. Ikeuchi, T. Ogura, R. Baba, K. Fujita, T. Fukui, F. Ito, S. Hattori, K. Yamamoto, T. Nakamoto, Y. Furusawa, A. Yasuhara, M. Ujie, S. Yamada, M. Ito, H. Mitsuya, N. Omagari, H. Yotsuyanagi, K. IwatsukiHorimoto, M. Imai, Y. Kawaoka, Comparison of Rapid Antigen Tests for COVID19, Viruses. 12 (2020). https://doi.org/10.3390/v12121420. 
medRxiv preprint doi: https://doi.org/10.1101/2021.06.09.21258157; this version posted June 13, 2021. The copyright holder for this preprint (which was not certified by peer review) is the author/funder, who has granted medRxiv a license to display the preprint in perpetuity.

It is made available under a CC-BY-NC-ND 4.0 International license

Table 1. Sensitivities and times to a positive reaction for three antigen tests

\begin{tabular}{lcc} 
& Sensitivity & Median time to a positive \\
& $(95 \% \mathrm{CI}), \%$ & reaction [IQR], sec \\
\hline QuickNavi ${ }^{\text {TM_COVID19 Ag }}$ & $87.5(79.2-93.4)$ & $15.0[12.0-33.3]$ \\
DK20-CoV-8M & $87.5(79.2-93.4)$ & $21.0[17.0-44.3]$ \\
DIA & $88.6(75.4-96.2)$ & - \\
\hline
\end{tabular}

CI, confidence interval; IQR, interquartile range; DIA, digital immunoassay

The time to a positive reaction was not available for DIA due to the nature of digital immunoassays. The running time of its reader is 15 minutes.

The RT-PCR of the N2 gene was used as a reference. 
medRxiv preprint doi: https://doi.org/10.1101/2021.06.09.21258157; this version posted June 13, 2021. The copyright holder for this preprint (which was not certified by peer review) is the author/funder, who has granted medRxiv a license to display the preprint in perpetuity.

It is made available under a CC-BY-NC-ND 4.0 International license.

\section{Figure Legends}

Figure 1. Workflow of a drive-through testing site at Tsukuba Medical Center Hospital. Abbreviation: NP, nasopharynx

Figure 2. Procedures for DK20-CoV-8M testing.

Figure 3. Relationship between the time to get positive results and sample $\mathrm{Ct}$ values. Circles indicate cases with positive antigen tests. The results of linear regression analyses are shown as dotted lines, along with their $\mathrm{p}$ values.

Figure 4. Comparison of results between QuickNavi ${ }^{\mathrm{TM}}-\mathrm{COVID} 19$ Ag and DIA.

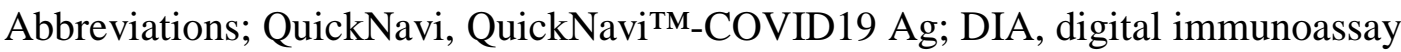

Supplementary Figure. Positive correlation between the time to get positive results obtained using QuickNaviTM_COVID19 Ag and DK20-CoV-8M. 
Morning-1PM

Referral
0:30PM-3PM

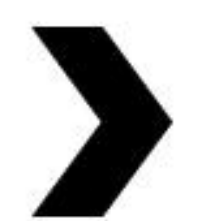

Sample collection

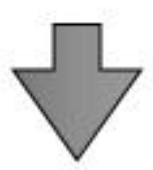

NP sampling for

- in-house PCR

- Digital immunoassay (DIA)
2PM-4PM

\section{Result Report}

$1-3 \mathrm{hr}$
4:30PM-5:30PM

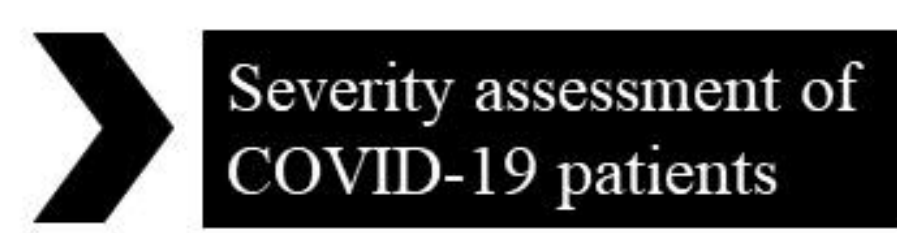

$1 \mathrm{hr}$

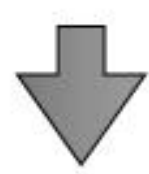

NP sampling for - QuickNavi ${ }^{\text {TM}}$-COVID19 Ag

- DK20-CoV-8M 


\section{Sample Preparation}

\section{Dip specimen}

soon after sampling

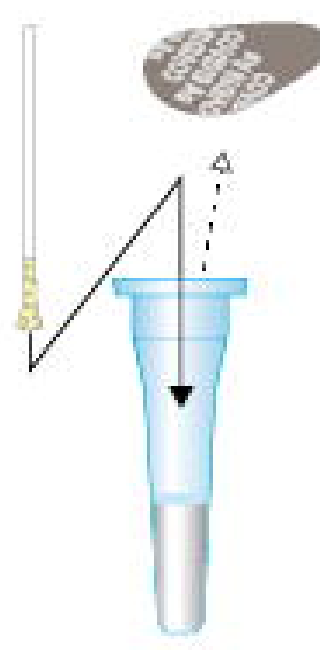

\section{Mix well}

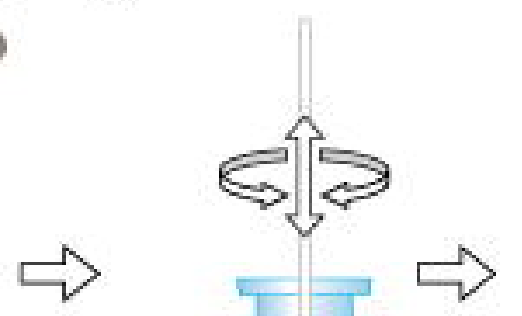

Reading Time $0 \sim 15 \mathrm{~min}$
Pinching
Take out swab

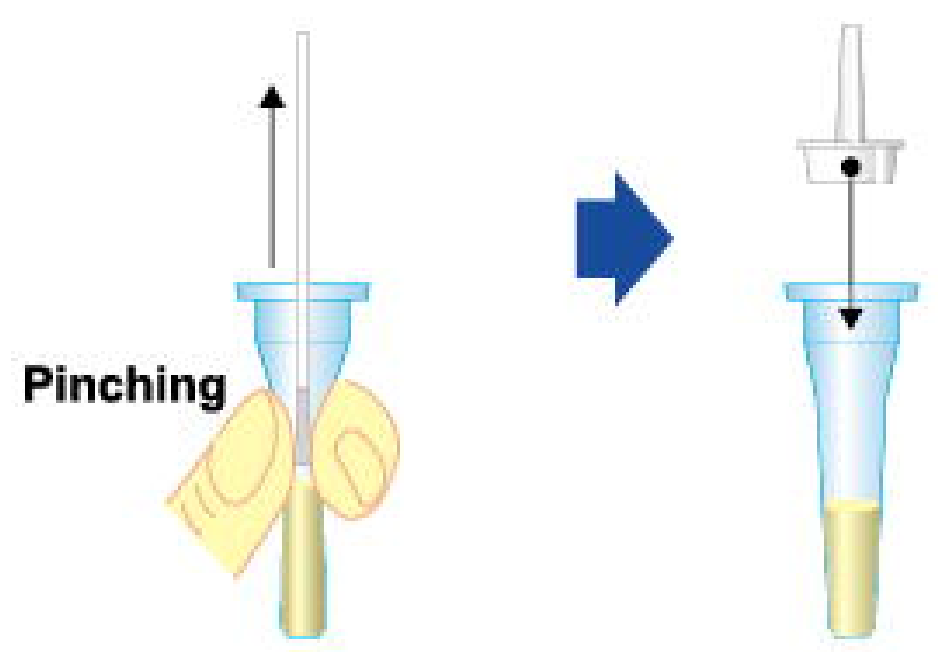

Putting Filter / Adding Sample Put Filter

Push tube

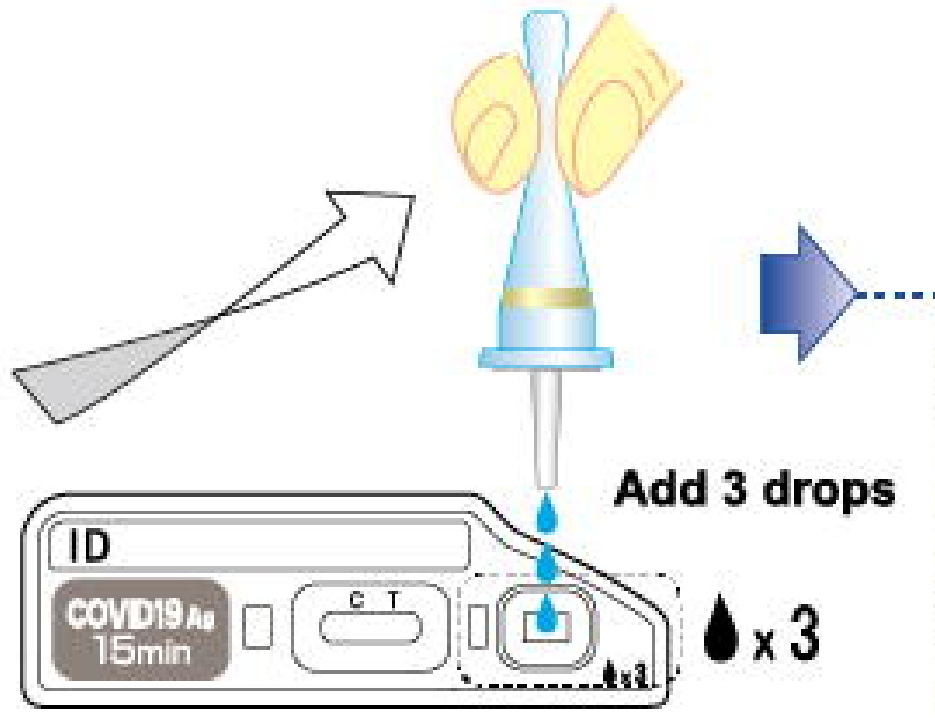

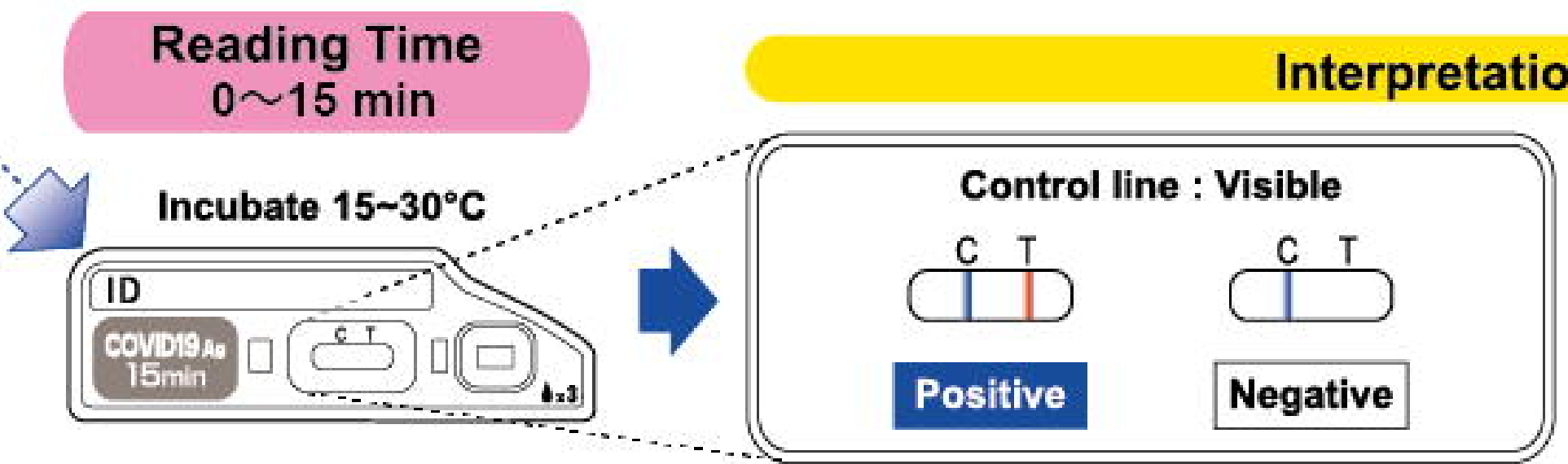

of Results

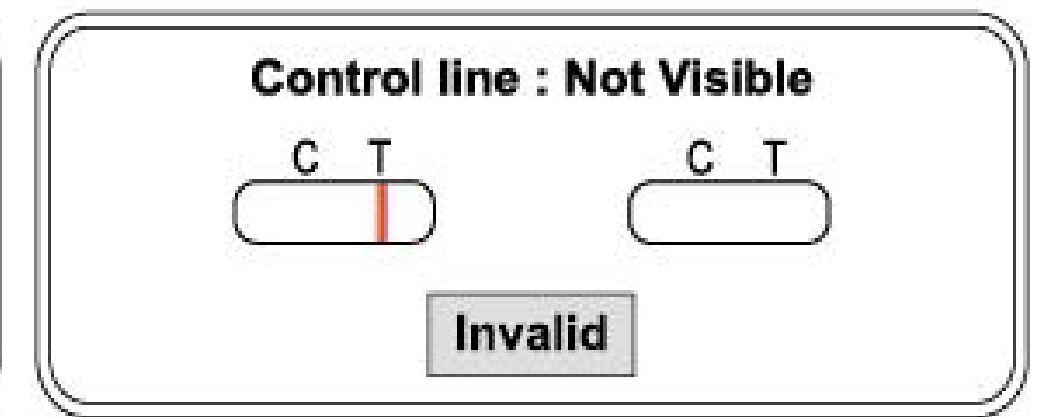




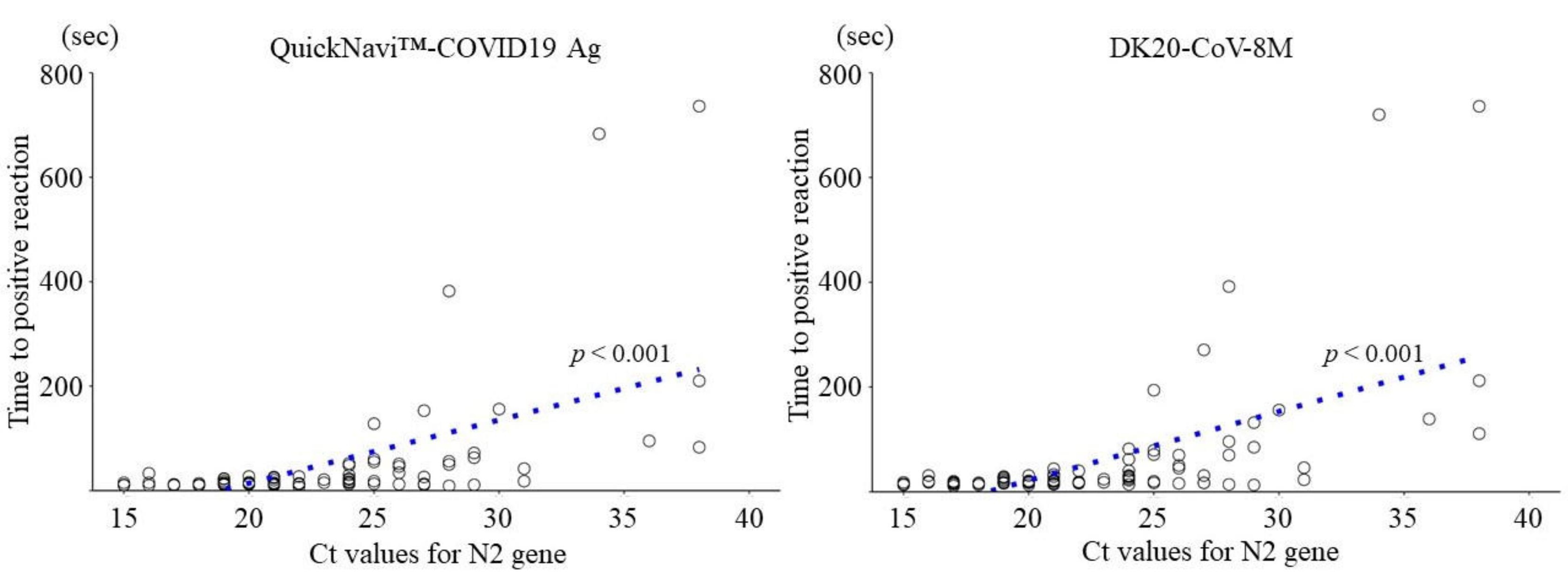


